\author{
Dr Joanna RUDAWSKA \\ Wydział Prawa i Nauk Społecznych, Uniwersytet Jana Kochanowskiego w Kielcach \\ e-mail: jrudawska@ujk.edu.pl \\ ORCID: 0000-0003-1484-8283
}

DOI: $10.15290 /$ oes.2021.02.104.05

\title{
CZY FIRMY PARKOWE SĄ BARDZIEJ INNOWACYJNE? PRZEGLĄD BADAŃ EMPIRYCZNYCH W POLSCE I NA ŚWIECIE ${ }^{1}$
}

\begin{abstract}
Streszczenie
Cel - Celem artykułu jest przegląd badań dotyczących funkcjonowania firm w parkach technologicznych i próba odpowiedzi na pytanie, czy firmy ulokowane w tego typu instytucjach są bardziej konkurencyjne, innowacyjne niż te spoza ośrodków innowacji, jakimi są parki technologiczne.

Metoda badan - W artykule wykorzystano wyniki studiów literatury przedmiotu, wyniki wcześniejszych badań autorki, jak również obserwacje praktyki gospodarczej w obszarze funkcjonowania parków technologicznych w Polsce. Jako podstawową metodę badawczą wykorzystano studia literaturowe.

Wyniki - Zestawienie wyników badań nie przynosi jednoznacznych wniosków dotyczących tego, czy firmy ulokowane w parkach technologicznych są bardziej innowacyjne, konkurencyjne na rynku niż te spoza. Wskazuja jednak na pewne elementy wyróżniające firmy parkowe na tle pozostałych w poszczególnych obszarach i metody użyte do ich badania.

Oryginalność / wartość - Przegląd obejmuje badania ze świata i z Polski, zestawione po raz pierwszy w takim zakresie, obejmujące prace opublikowane po roku 2000, dotyczące zatem parków technologicznych czwartej generacji rozwoju tego typu instytucji.
\end{abstract}

Słowa kluczowe: ośrodki innowacji, park technologiczny, firma innowacyjna

\section{ARE PARK COMPANIES MORE INNOVATIVE? A REVIEW OF EMPIRICAL RESEARCH IN POLAND AND IN THE WORLD}

\section{Summary}

Pupose - The aim of the article is to review the research on the functioning of companies in technology parks and to try to answer the question whether companies located in such institutions are more competitive and innovative than those outside innovation centers, such as technology parks.

Research method - The article uses the results of literature studies on the subject, the results of the author's previous research, as well as observations of economic practice in the field of technology parks in Poland. Literature studies were used as the basic research method.

Results - The summary of the research results does not provide unequivocal results as to whether companies located in technology parks are more innovative, competitive on the market than those outside of them. However, they indicate certain elements that distinguish park companies from others in individual areas and the methods used to study them.

1 Artykuł wpłynął 10 lutego 2021 r., zaakceptowano 16 kwietnia 2021 r. 
Originality / value - The review covers research from around the world and from Poland, compiled for the first time in this respect, including works published after 2000, covering technology parks of the fourth generation of development of such institutions.

Keywords: innovation units, technology park, innovative company

JEL Classification: M13

\section{Wstęp}

$\mathrm{Na}$ świecie funkcjonuje obecnie około 900 parków technologicznych w 70 krajach, w tym 365 na obszarze Unii Europejskiej [IASP, 2018]. Polska Agencja Rozwoju Przedsiębiorczości identyfikuje 43 podmioty tego typu [Gotowość Ośrodków Innowacji..., 2021]. Stowarzyszenie Organizatorów Ośrodków Innowacji i Przedsiębiorczości zaś w badaniu z 2019 roku podkreśla funkcjonowanie tylko 32 aktywnych i wpisujących się w definicję takich ośrodków innowacji [Mażewska, Tórz, 2019]. Parki technologiczne różnia się między sobą lokalizacja, wiekiem, wielkością, modelem biznesowym, specjalizacją i forma prawna, jednak przyświeca im zbieżny cel, jakim jest transfer wiedzy naukowej do gospodarki rynkowej oraz rozwój innowacyjnych firm. Badania firm funkcjonujących w infrastrukturze parków technologicznych prowadzone są z różnych perspektyw na całym świecie. Grupa tych firm jest ciekawym dla badaczy respondentem, ponieważ ulokowana jest w ośrodkach innowacji dysponujących zróżnicowaną ofertą wsparcia rozwoju, wdrażania innowacji i procesu transferu technologii [Wójcik-Karpacz, Rudawska, 2016, s. 250]. Oczekiwać więc można, że firmy korzystające z oferty, często bezpłatnie lub na warunkach preferencyjnych, dzięki łatwiejszemu dostępowi do programów, narzędzi i infrastruktury odnotowują lepsze wyniki zarówno te finansowe, jak i pozafinansowe niźli firmy niedziałające $\mathrm{w}$ tym środowisku. Badania porównawcze tych dwóch grup firm, w i spoza instytucji, stanowia jednocześnie badanie efektywności funkcjonowania parków technologicznych [Pelle i in., 2008, s. 13]. Wyniki prowadzonych na świecie i w Polsce badań na firmach parkowych i spoza parków nie sa jednak jednoznaczne, co stanowi podstawę do dalszego rozpoznania zagadnienia i poszukiwania odpowiedzi na pytanie, co jeszcze decyduje o konkurencyjności i innowacyjności firm.

$\mathrm{W}$ artykule omówiono podstawowe definicje związane z parkami technologicznymi, ich ofertą wsparcia dla firm innowacyjnych, a następnie dokonano przeglądu badań naukowych po roku 2000 zarówno w Polsce, jak i na świecie, analizujących oddziaływanie parków na wyniki ulokowanych w nich firm. Wyciagnięte wnioski moga posłużyć w praktyce do wypracowania przez parki dedykowanych systemów monitoringu i ewaluacji działań, biorąc pod uwagę perspektywę klienta, jakim są firmy lokatorzy. Moga przydać się również menedżerom parku do modyfikacji oferty ośrodka, by podkreślać efektywność jego działalności. 


\section{Parki technologiczne i ich rola we wsparciu firm innowacyjnych}

Za najbardziej kompleksową formę instytucjonalnego wsparcia ekosystemu innowacji i przedsiębiorczości uznaje się ośrodki innowacji, jakimi są parki technologiczne [Wójcik-Karpacz, Rudawska, 2016, s. 250]. Zgodnie z definicją Międzynarodowego Stowarzyszenia IASP [2002] są instytucjami zarządzanymi przez wykwalifikowanych specjalistów, a ich celem jest podniesienie dobrobytu społeczności zamieszkującej obszar, w którym działają. Proces ten zachodzi poprzez promowanie kultury innowacji i konkurencji wśród przedsiębiorców i instytucji opartych na wiedzy, animację współpracy z sektorem nauki, sieciowanie podmiotów, internacjonalizację $\mathrm{i}$ oferowanie dostępu do infrastruktury w celu stwarzania optymalnych warunków do rozwoju projektów innowacyjnych.

Parki technologiczne rozwijały się od lat 50. XX wieku, początkowo w Stanach Zjednoczonych. Model pchany przez naukę (science push) oznaczał, że tworzone były w obrębie kampusu akademickiego i formalnie związane $z$ uczelnią, na rzecz której generowały rozwiązania. $Z$ czasem coraz większe zainteresowanie tego typu inicjatywami rynku spowodowało, że kierunek rozwoju i specjalizację parków wyznaczały potrzeby firm (demand pull), co nazwano druga generacją parków technologicznych [Strategiczne obszary rozwoju..., 2011, s. 17-19]. Parki trzeciej generacji są traktowane jako elementy systemów innowacji zarówno regionalnych, jak i narodowych. Zostały zdefiniowane w 2006 [Allen, 2007, s. 8], a zakres ich działania polega na stwarzaniu przestrzeni i warunków formalnych i nieformalnych, sprzyjających wsparciu środowiska wysoko innowacyjnego. Rowe [2003, s. 34] identyfikuje czwarta generację parków, powstających po 2000 roku, które działaja globalnie, tworzą rozległe sieci ponadnarodowe, transferują wiedzę oraz technologię. Cechą tej generacji jest wielorakość podmiotów zaangażowanych w sieć współpracy i nacisk na dzielenie się wiedzą.

Nie ma szablonowego modelu parku technologicznego. Można wyróżnić kilka elementów dywersyfikujących parki technologiczne, takich jak: wiek, wielkość, lokalizacja, struktura właścicielska, model biznesowy, poziom specjalizacji, lokatorzy, rodzaj wsparcia, sposób zarządzania, relacje z interesariuszami zewnętrznymi [Albahari, 2019, s. 4]. Z uwagi na funkcje parku dzielą się one na parki przemysłowe, nakierowane na przyciagnie inwestorów oraz kreowanie miejsc pracy, niekoncentrujące się na działalności innowacyjnej. Drugą kategorią są parki naukowe (naukowo-technologiczne), działające w ścisłej współpracy z jednostką czy jednostkami naukowymi, skupiające się na transferze wiedzy i technologii. Popularne są parki technologiczne (przemysłowo- i naukowo-technologiczne) kierujące swoją ofertę usług do firm wykorzystujących nowoczesne technologie na różnym poziomie rozwoju, niekoniecznie w powiązaniu z jednostką naukową [Wójcik-Karpacz, Rudawska, 2016, s. 250]. Tym, co łączy definicje parków technologicznych, jest oferta wsparcia dla przedsiębiorstw innowacyjnych w zakresie między innymi:

- szkoleń i doradztwa w tworzeniu i rozwoju przedsiębiorstw,

- optymalizacji warunków do transferu wiedzy i technologii, komercjalizacji wyników badań do praktyki gospodarczej, 
- dyfuzji innowacji,

- przekształcania wyników badań naukowych i prac rozwojowych w innowacje,

- tworzenia sprzyjających warunków do prowadzenia innowacyjnej działalności gospodarczej i wspomaganie innowatorów w zaawansowanych technologicznie branżach [Innowacje i transfer technologii..., 2005; Wójcik-Karpacz, Rudawska, 2016, s. 250].

Parki sa zatem traktowane jako instrument prorozwojowy i proinnowacyjny.

\section{Wybrane badania firm parkowych na świecie i w Polsce - studia literaturowe}

Efektywność parków technologicznych jest zagadnieniem chętnie podejmowanym w literaturze [Lyra, Almeida, 2018, s. 2-3]. Wynika to z faktu, że parki technologiczne są często finansowo wspierane przez sektor publiczny, który wymaga transparentnego rozliczenia z rezultatów osiagniętych dzięki wydatkowanym środkom. Co więcej, parki same potrzebuja pozytywnego wizerunkowego przesłania, że są skuteczne, po to, aby pozyskiwać nowe innowacyjne firmy zasiedlające ich infrastrukturę oraz środki zewnętrzne na inwestycje. Wyniki osiagane przez park są niezbędne także do oceny samych menedżerów i skuteczności ich strategii zarządzania [Monck, Peters, 2009; Cardy, Leonard, 2011]. Przyjęcie jednej określonej metody monitoringu i ewaluacji, w tym jednolitych wskaźników, nie jest jednak zadaniem prostym. Trudność wynika z różnorodności inicjatyw parkowych, w tym: fazy rozwoju parku, formy prawnej, modelu biznesowego, rodzaju i liczby udziałowców, wielkości zarządzanej infrastruktury, lokalizacji, celów postawionych przed organizacją i innych zmiennych [Dąbrowska, 2011, s. 3].

Jedna z form badania efektywności parku, obok badania potencjału samych instytucji i relacji z sektorem nauki, jest porównanie firm parkowych z próbką firm spoza parku [Lyra, Almeida, 2018, s. 2-3]. Wydaje się, że ocena skuteczności oferty wsparcia parku technologicznego z perspektywy klienta (z ang. stakeholder perspective, client perspective) jest miarą rzetelna, obiektywna, choć wątpliwość często budzą sposób i kryteria doboru próbki firm spoza parku do badania porównawczego [Dąbrowska, 2011, s. 2].

Dokonując przeglądu literatury krajowej i zagranicznej (po roku 2000)² w zakresie potencjału wzrostu i rozwoju, potencjału innowacyjnego oraz badawczo-rozwojowego firm ulokowanych w parkach i inkubatorach technologicznych, można napotkać skrajne wyniki badań porównawczych prowadzonych na firmach funkcjonujących w ekosystemie tworzonym przez ośrodki innowacji, jakimi sa parki technologiczne. Spis wybranych badań oraz kluczowe wnioski ujęto w tabelach 1 i 2.

\footnotetext{
2 Pierwszy park na świecie powstał w 1948 w Stanach Zjednoczonych, w Europie w latach 70. (1969), w Polsce w 1995. Przyjęto do badań ostatnie 20 lat, czyli publikacje powstające po 2000 roku, co pozwala na odniesienie się do doświadczeń zarówno na świecie, jak i w Polsce w zakresie parków trzeciej i czwartej generacji.
} 
TABELA 1

\section{Zestawienie wybranych badań dotyczących sytuacji firm parkowych na świecie}

\begin{tabular}{|c|c|c|c|}
\hline $\begin{array}{l}\text { Autor / tytuł } \\
\text { opracowania }\end{array}$ & $\begin{array}{l}\text { Państwo } \\
\text { badania }\end{array}$ & Podmiot badania & Kluczowe wnioski \\
\hline $\begin{array}{l}\text { Squicciarini } \\
\text { [2008] }\end{array}$ & Finlandia & $\begin{array}{l}48 \text { firm z parków } \\
\text { i } 72 \text { firmy spoza } \\
\text { parków. }\end{array}$ & $\begin{array}{l}\text { Firmy parkowe sa aktywniejsze } \\
\text { w ochronie własności } \\
\text { intelektualnej. }\end{array}$ \\
\hline Westhead [2002] & $\begin{array}{l}\text { Wielka } \\
\text { Brytania }\end{array}$ & $\begin{array}{l}137 \text { firm z i spoza } \\
\text { parków technolo- } \\
\text { gicznych. }\end{array}$ & $\begin{array}{l}\text { Wyniki firm w obu próbach nie } \\
\text { różnią się pod katem innowacyj- } \\
\text { ności. }\end{array}$ \\
\hline $\begin{array}{l}\text { Siegel, Westhead } \\
\text { Wright [2003] }\end{array}$ & $\begin{array}{l}\text { Wielka } \\
\text { Brytania }\end{array}$ & $\begin{array}{l}89 \text { firm z i } 89 \\
\text { spoza parków } \\
\text { technologicznych. }\end{array}$ & $\begin{array}{l}\text { Firmy parkowe są aktywniejsze } \\
\text { w obszarze B+R, wprowadzają } \\
\text { więcej nowych produktów. }\end{array}$ \\
\hline $\begin{array}{l}\text { Evaluation of the } \\
\text { past and future } \\
\text { economic contri- } \\
\text { bution of the UK } \\
\text { Science Park } \\
\text { Movement [2003] }\end{array}$ & $\begin{array}{l}\text { Wielka } \\
\text { Brytania }\end{array}$ & $\begin{array}{l}617 \text { firm } \\
\text { parkowych i } 269 \\
\text { spoza parków. }\end{array}$ & $\begin{array}{l}\text { Firmy parkowe generują większe } \\
\text { przychody i zatrudniają } 10 \% \text { więcej } \\
\text { pracowników. }\end{array}$ \\
\hline $\begin{array}{l}\text { Lindelöf, } \\
\text { Löfsten [2002] }\end{array}$ & Szwecja & $\begin{array}{l}134 \text { firmy } \\
\text { parkowe, } \\
139 \text { firm } \\
\text { pozaparkowych. }\end{array}$ & $\begin{array}{l}\text { Firmy parkowe rozwijają się } \\
\text { szybciej pod względem zatrud- } \\
\text { niania i sprzedaży. Wyniki } \\
\text { finansowe (zysk) - różnica jest } \\
\text { nieistotna. }\end{array}$ \\
\hline $\begin{array}{l}\text { Lindelöf, } \\
\text { Löfsten [2003] }\end{array}$ & Szwecja & $\begin{array}{l}134 \text { firmy } \\
\text { parkowe, } \\
139 \text { firm } \\
\text { pozaparkowych. }\end{array}$ & $\begin{array}{l}\text { Nie odnotowano znaczacych } \\
\text { różnic w obszarze działalności } \\
\text { rozwojowej i liczby nowych } \\
\text { produktów i usług. Firmy parkowe } \\
\text { mają wyższy potencjał rozwoju. }\end{array}$ \\
\hline $\begin{array}{l}\text { Lindelöf, } \\
\text { Löfsten [2004] }\end{array}$ & Szwecja & $\begin{array}{l}134 \text { firmy } \\
\text { parkowe, } \\
139 \text { firm } \\
\text { pozaparkowych. }\end{array}$ & $\begin{array}{l}\text { Nie odnotowano znaczącej różnicy } \\
\text { pomiędzy aktywnością B+R firm } \\
\text { parkowych. Firmy ulokowane } \\
\text { w parku mają więcej powiązań } \\
\text { z uczelniami oraz dynamiczniej się } \\
\text { rozwijają. }\end{array}$ \\
\hline $\begin{array}{l}\text { Lindelöf, } \\
\text { Löfsten [2005] }\end{array}$ & Szwecja & $\begin{array}{l}134 \text { firmy } \\
\text { parkowe, } \\
139 \text { firm } \\
\text { pozaparkowych. }\end{array}$ & $\begin{array}{l}\text { Nie odnotowano znaczacych } \\
\text { różnic w poziomie generowania } \\
\text { zysku firm parkowych. }\end{array}$ \\
\hline $\begin{array}{l}\text { Ferguson, } \\
\text { Olofsson [2004] }\end{array}$ & Szwecja & $\begin{array}{l}30 \text { firm parko- } \\
\text { wych i } 36 \text { spoza } \\
\text { parków. }\end{array}$ & $\begin{array}{l}\text { Więcej firm inkubowanych } \\
\text { w parkach kontynuuje działalność } \\
\text { na rynku. }\end{array}$ \\
\hline
\end{tabular}


Czy firmy parkowe są bardziej innowacyjne? Przegląd badań empirycznych... 63

\begin{tabular}{|c|c|c|c|}
\hline $\begin{array}{l}\text { Autor / tytuł } \\
\text { opracowania }\end{array}$ & $\begin{array}{l}\text { Państwo } \\
\text { badania }\end{array}$ & Podmiot badania & Kluczowe wnioski \\
\hline $\begin{array}{l}\text { Albahari, Barge- } \\
\text { Gil, Pérez-Canto, } \\
\text { Modrego-Rico } \\
\text { [2013] }\end{array}$ & Hiszpania & $\begin{array}{l}849 \text { firm } \\
\text { i } 25 \text { parków } \\
\text { technologicznych. }\end{array}$ & $\begin{array}{l}\text { Firm parkowe mają większą } \\
\text { skłonność do angażowania się we } \\
\text { współpracę w zakresie projektów } \\
\text { innowacyjnych. }\end{array}$ \\
\hline $\begin{array}{l}\text { Vásquez-Urriago, } \\
\text { Barge-Gil, } \\
\text { Paraskevopoulou } \\
\text { [2011] }\end{array}$ & Hiszpania & $\begin{array}{l}653 \text { firmy parko- } \\
\text { we z } 22 \text { parków, } \\
39069 \text { firm spoza } \\
\text { parków. }\end{array}$ & $\begin{array}{l}\text { Wejście firmy do parku techno- } \\
\text { logicznego zwiększa skłonność } \\
\text { firm do kooperacji w zakresie } \\
\text { innowacji. }\end{array}$ \\
\hline $\begin{array}{l}\text { Vasquez-Urriago, } \\
\text { Barge-Gil, } \\
\text { Modrego Rico } \\
\text { [2016] }\end{array}$ & Hiszpania & Firmy parkowe. & $\begin{array}{l}\text { Większa skłonność firm parko- } \\
\text { wych do angażowania się we } \\
\text { współpracę w zakresie projektów } \\
\text { innowacyjnych. }\end{array}$ \\
\hline $\begin{array}{l}\text { Chan, Oerle- } \\
\text { mans, Pretorius } \\
{[2010]}\end{array}$ & $\begin{array}{l}\text { Afryka } \\
\text { Południowa }\end{array}$ & $\begin{array}{l}47 \text { firm parko- } \\
\text { wych i firmy } \\
\text { pozaparkowe. }\end{array}$ & $\begin{array}{l}\text { Wyniki firm obu prób nie różnią } \\
\text { się. }\end{array}$ \\
\hline $\begin{array}{l}\text { Fukagawa } \\
{[2006]}\end{array}$ & Japonia & $\begin{array}{l}74 \text { firmy } \\
\text { parkowe, } 138 \\
\text { firm spoza parku. }\end{array}$ & $\begin{array}{l}\text { Odnotowano większą liczbę } \\
\text { powiązań firm parkowych } \\
\text { z uczelniami niż firm spoza parku. } \\
\text { Firmy w parkach są bardziej chętne } \\
\text { do angażowania się w projekty } \\
\text { badawczo-rozwojowe. }\end{array}$ \\
\hline $\begin{array}{l}\text { Yang, Moto- } \\
\text { hashi, Chen } \\
\text { [2009] }\end{array}$ & Tajwan & $\begin{array}{l}57 \text { firm parko- } \\
\text { wych, } 190 \text { spoza } \\
\text { parków. }\end{array}$ & $\begin{array}{l}\text { Firmy parkowe są aktywniejsze } \\
\text { w obszarze B+R. }\end{array}$ \\
\hline $\begin{array}{l}\text { Malairaja, } \\
\text { Zawdie [2008] }\end{array}$ & Malezja & $\begin{array}{l}22 \text { firmy } \\
\text { parkowe, } 30 \text { firm } \\
\text { spoza parków. }\end{array}$ & $\begin{array}{l}\text { Firmy parkowe są aktywniejsze } \\
\text { w obszarze B+R. }\end{array}$ \\
\hline $\begin{array}{l}\text { Colombo, } \\
\text { Delmastro } \\
{[2002]}\end{array}$ & Włochy & $\begin{array}{l}45 \text { firm parko- } \\
\text { wych i } 45 \text { spoza } \\
\text { parku (grupa } \\
\text { kontrolna). }\end{array}$ & $\begin{array}{l}\text { Firmy parkowe mają szybsze } \\
\text { tempo wzrostu, szybciej akumulują } \\
\text { kapitał ludzki, szybciej się rozwijają } \\
\text { i są bardziej skłonne do współ- } \\
\text { pracy, również międzynarodowej, } \\
\text { niż firmy spoza parku; nie różnią } \\
\text { się natomiast liczbą patentów. }\end{array}$ \\
\hline $\begin{array}{l}\text { Lamperti, } \\
\text { Mavilia, } \\
\text { Castellini [2017] }\end{array}$ & Włochy & $\begin{array}{l}32 \text { parki, w tym } \\
148 \text { firm } \\
\text { parkowych. }\end{array}$ & $\begin{array}{l}\text { Firmy parkowe są bardziej aktywne } \\
\text { pod katem innowacji i inwestycji } \\
\text { w badania. Lokalizacja w parku nie } \\
\text { jest powiązana ze wzrostem firmy. }\end{array}$ \\
\hline $\begin{array}{l}\text { Leyden, Link, } \\
\text { Siegel [2014] }\end{array}$ & $\begin{array}{l}\text { Stany } \\
\text { Zjednoczone }\end{array}$ & $\begin{array}{l}\text { Firmy parkowe } \\
\text { i spoza parku. }\end{array}$ & $\begin{array}{l}\text { Firmy parkowe mają większy } \\
\text { potencjał rozwoju, cechują się } \\
\text { większą różnorodnością i wynikami } \\
\text { badawczymi niż firmy spoza parku. }\end{array}$ \\
\hline
\end{tabular}

Źródło: opracowanie własne. 
Biorąc pod uwage aktywność firm parkowych w zakresie ochrony własności intelektualnej, badania porównawcze prowadzone przez Squicciarini [2008] na 252 firmach parkowych i pozaparkowych w Finlandii w latach 1970-2002 wskazały na większą aktywność tych firm $\mathrm{w}$ zakresie patentowania niż przedsiębiorstw funkcjonujących poza infrastruktura wsparcia innowacji. Do podobnych wyników doszli badacze Siegel, Westhead i Wright [2003], którzy przebadali 177 firm z i spoza parku w Wielkiej Brytanii pod kątem ekonometrycznego modelu funkcji badawczo-rozwojowej. Podkreślili oni, że lokatorzy parków technologicznych są bardziej produktywni pod kątem $B+R$, mają więcej patentów, wprowadzają więcej nowych produktów, co świadczy o ich wyższej efektywności badawczej i innowacyjnej. Również badania prowadzone przez Yang, Motohashi i Chen [2009] na Tajwanie i w Malezji [2008] podkreślały większą aktywność w działalności B+R lokatorów ośrodków innowacji.

Natomiast badania Chan i inni [2010] porównawcze w Południowej Afryce wskazują, że wyniki innowacyjne firm w parkach i spoza nich nie różnią się, choć firmy parkowe mają większe zaufanie na poziomie organizacyjnym i więcej powiązań z podmiotami spoza parku. Do podobnych wniosków doszedł Westhead [2002], badając 137 firm w Wielkiej Brytanii. Nie odnotował on istotnej statystycznie różnicy pomiędzy innowacyjnością firm ulokowanych w parkach technologicznych i tymi, które funkcjonuja poza infrastruktura. Kryteria brane pod uwagę, tj. udział pracowników o wykształceniu technicznym, wydatki na badania, liczba patentów, nowych usług i produktów nie różniły się znacząco, biorąc pod uwagę te odnotowane w badaniach porównawczych. Ferguson i Olofsoon [2004] również nie dostrzegli znaczącej różnicy we wzroście i rozwoju firm parkowych, zauważyli jednak, że więcej firm rozpoczynających działalność opierającą się na inkubacji, kontynuuje działalność na rynku.

Intensywne badania $\mathrm{w}$ tym zakresie prowadzili w Szwecji badacze Lindelöf i Löfsten [2002, 2003, 2004, 2005]. Doszli oni do wniosku, że firmy w parkach rozwijaja się tylko nieznacznie szybciej niż te poza parkiem pod kątem dynamiki zatrudnienia i sprzedaży, mają więcej relacji z uczelniami, ale jeśli chodzi o wyniki finansowe, to nie odnotowano znaczących różnic; podobnie w zakresie aktywności badawczo-rozwojowej.

W świetle badań intensywność współpracy firm lokatorów parków technologicznych z uczelniami jest wyższa niż firm spoza tych ośrodków. Moment wejścia firmy do parku technologicznego według badań przeprowadzonych na firmach parkowych w Hiszpanii (2011 i 2016) oraz Litwie (2010) wpływa na zwiększenie skłonności tych firm do angażowania się we współpracę w zakresie projektów innowacyjnych. Również badania Fukugawa w Japonii wykazały większą liczbę powiązań parkowych z uczelniami niż firm spoza parku. Podobnie Lamperti, Mavilia i Castellini [2017] przebadali grupe kontrolną, używając 3 zmiennych: wzrost firm, innowacyjność (wnioski patentowe) oraz inwestycje w działania B+R. Doszli do wniosku, że lokatorzy parków są bardziej aktywni w pozyskiwaniu i wdrażaniu projektów innowacyjnych, chętni do inwestycji związanych z pracami badawczymi, 
a wydatki na badania i liczba patentów (innowacyjność) firm parkowych jest wyższa niż tych spoza parku.

Regularne badania firm brytyjskich w parkach prowadzi stowarzyszenie UKSPA (The United Kingdom Science Park Association), [Evaluation of the ..., 2003]. Ich wyniki dowodzą, że firmy ulokowane w parkach technologicznych cechują się lepszą sytuacją ekonomiczna, zatrudniają około $10 \%$ więcej pracowników niż te spoza parków i generuja większe przychody. Podobne wyniki zaprezentowali badacze Colomba i Delmastro [2002], badający firmy parkowe we Włoszech. Według nich firmy działające w infrastrukturze parkowej mają szybsze tempo wzrostu, szybciej akumulują kapitał ludzki, szybciej się rozwijają i są bardziej skłonne do współpracy, również międzynarodowej, niż firmy spoza parku; nie różnią się natomiast liczbą patentów.

Do ciekawych wniosków w swoich badaniach doszli Albahari i inni [2013]. Przebadali oni hiszpańskie parki technologiczne oraz ulokowane w nich firmy, szukając zależności pomiędzy wynikami finansowymi lokatorów a wiekiem i wielkością parków, w których są ulokowane. Odkryli, że firmy w większych parkach mają wyższe wyniki finansowe niż te $\mathrm{w}$ parkach małych. Jeśli chodzi o wiek parku, to firmy działające w parkach najmłodszych i najstarszych osiagaja lepsze wyniki, aniżeli te ulokowane w parkach o średnim wieku. Badacze tłumaczą to zjawisko podwójnym wpływem lokalizacji na terenie parku: początkowy, krótkoterminowy pozytywny wpływ na firmę generowany jest przez jej widoczność i prestiz lokalizacji w parku. $Z$ drugiej strony parki starsze dysponują bazą wiedzy i lepszym zrozumiem potrzeb najemców i bardziej skutecznym wsparciem biznesu.

Badania porównawcze firm parkowych i spoza parków w Polsce nie są popularne wśród naukowców i stosunkowo rzadko realizowane. W literaturze można znaleźć natomiast badania samych ośrodków technologicznych bądź wyłącznie parków technologicznych realizowanych przez SOOIPP, Polską Agencję Rozwoju Przedsiębiorczości, Ministerstwo Rozwoju, Pracy i Technologii. W przeglądzie skupiono się na badaniach dotyczacych wyłącznie firm parkowych. Zestawienie wybranych badań zrealizowanych w Polsce zawarto w tabeli 2 .

Cykliczne badania firm ulokowanych w parkach i inkubatorach technologicznych, dające możliwość analizy porównawczej między latami, prowadzone są przez Stowarzyszenie Organizatorów Ośrodków Innowacji i Przedsiębiorczości w Polsce [www 1], które dysponuje jedyną w Polsce bazą firm parkowych za lata 2009-2020, uzupełniana przez członków stowarzyszenia. Badania prezentują zmiany w stanie firm parkowych $i$ inkubatorowych na przestrzeni lat i odnoszą się do różnych obszarów tematycznych m.in. transferu wiedzy i technologii, internacjonalizacji, koncepcji Przemysłu 4.0. Badanie firm w roku 2012 i 2013 wskazywało, iż firmy utrzymuja aktywność w obszarze innowacyjnych kierunków działania i aktywnie współpracuja z sektorem nauki. Badanie opublikowane przez SOOIPP w 2020 roku [Borowy i in., 2020], obejmujące dane za 2019, wskazuje, że innowacyjność firm ulokowanych w polskich parkach i inkubatorach technologicznych jest wyższa od przeciętnej krajowej. Również stopień internacjonalizacji tych przedsiębiorstw jest wyższy od pozostałych polskich firm sektora MSP. Badania w kontekście nowych 
trendów jak Industry 4.0, wykazały, iż blisko połowa badanych podmiotów podejmuje działania spójne z kierunkami rewolucji przemysłowej 4.0. Pogłębione badania natomiast wykazują, że aż $20 \%$ firm nie wdrożyło żadnej innowacji. Tymi, które można zakwalifikować do wysokotechnologicznych, są głównie firmy usługowe. Wśród badanych firm nie jest popularna ochrona własności intelektualnej, również niewielka ich część (1/5) uczestniczy w działaniach klastrów i innych sieciach współpracy.

TABELA 2

Przegląd badań dotyczących firm parkowych realizowanych w Polsce

\begin{tabular}{|c|c|c|c|}
\hline $\begin{array}{l}\text { Autor / tytuł } \\
\text { opracowania }\end{array}$ & $\begin{array}{l}\text { Państwo } \\
\text { badania }\end{array}$ & $\begin{array}{l}\text { Podmiot } \\
\text { badania }\end{array}$ & Kluczowe wnioski \\
\hline $\begin{array}{l}\text { Hołub-Iwan, } \\
\text { Olczak, Cheba } \\
{[2012]}\end{array}$ & Polska & $\begin{array}{l}495 \text { firm } \\
\text { parkowych. }\end{array}$ & $\begin{array}{l}\text { W badaniu zawarto pytanie o wpływ } \\
\text { parku na sukces firmy. Odpowiedzi } \\
\text { firm były poniżej średniej (in minus), } \\
\text { co uznawane jest za ocenę negatywną. }\end{array}$ \\
\hline $\begin{array}{l}\text { Raport o firmach } \\
\text { driatajacych w parkach } \\
\text { i inkubatorach techno- } \\
\text { logicznych w Polsce } \\
\text { w } 2012 r . \text { [2012] }\end{array}$ & Polska & $\begin{array}{l}\text { Analiza bazy } \\
\text { firm - } 899 \\
\text { ankieta pogłę- } \\
\text { biona - } 289\end{array}$ & $\begin{array}{l}\text { Udział innowacyjnych produktów / } \\
\text { usług w całej sprzedaży firm } \\
\text { ulokowanych w badanych parkach } \\
\text { wynosił średnio tylko około } 2,4 \% \\
\text { (należy zwrócić uwagę, że rozrzut był } \\
\text { od } 3 \text { do } 100 \% \text { ). }\end{array}$ \\
\hline $\begin{array}{l}\text { Raport o firmach } \\
\text { driatajacych w parkach } \\
\text { i inkubatorach techno- } \\
\text { logicznych w Polsce } \\
\text { w } 2014 \text { r. [2014] }\end{array}$ & Polska & $\begin{array}{l}\text { Analiza bazy } \\
\text { firm - } 1157, \\
\text { ankieta pogłę- } \\
\text { biona }-289 \text {. }\end{array}$ & $\begin{array}{l}\text { W badaniu wyodrębniono firmy } \\
\text { innowacyjne (PKD), które stanowiły } \\
45,46 \% \text { próby. Firmy parkowe sa } \\
\text { bardziej innowacyjne niż firmy } \\
\text { działające w inkubatorach i aktywnie } \\
\text { współpracuja ze środowiskiem } \\
\text { naukowym, w tym zatrudniaja } \\
\text { naukowców. }\end{array}$ \\
\hline $\begin{array}{l}\text { Prezentacja wyników } \\
\text { badań o firmach } \\
\text { dziatajacych w parkach } \\
\text { i inkubatorach techno- } \\
\text { logicznych w Polsce } \\
w 2017 r .[2017]\end{array}$ & Polska & $\begin{array}{l}\text { Analiza bazy } \\
\text { firm - } 1562, \\
\text { ankieta pogłę- } \\
\text { biona }-220 \text {. }\end{array}$ & $\begin{array}{l}\text { Firmy parkowe średnio wdrażają } \\
2 \text { innowacje o zasięgu regionalnym } \\
\text { i krajowym. Usług doradczych } \\
\text { szukają częściej wśród firm konsul- } \\
\text { tingowych niż zasobów kadrowych } \\
\text { parku. }\end{array}$ \\
\hline Kwieciński [2018] & Polska & $\begin{array}{l}300 \text { firm } \\
\text { parkowych. }\end{array}$ & $\begin{array}{l}\text { Odsetek firm innowacyjnych } \\
\text { w parkach jest niewielki i wynosi } \\
20 \% \text {, aż połowa jest nieinnowacyjna, } \\
\text { tylko } 31 \% \text { ma ograniczony potencjał } \\
\text { do kreowania innowacji. }\end{array}$ \\
\hline $\begin{array}{l}\text { Borowy, Mażewska, } \\
\text { Rudawska [2020] }\end{array}$ & Polska & $\begin{array}{l}\text { Analiza bazy } \\
\text { firm - } 1286, \\
\text { ankieta pogłę- } \\
\text { biona }-177 \text {. }\end{array}$ & $\begin{array}{l}\text { Innowacyjność, stopień internacjo- } \\
\text { nalizacji firm parkowych są wyższe } \\
\text { od przeciętnej krajowej. }\end{array}$ \\
\hline
\end{tabular}

Źródło: opracowanie własne. 
Oprócz cyklicznych badań prowadzonych przez Stowarzyszenie Organizatorów Ośrodków Innowacji i Przedsiębiorczości w Polsce można wskazać prowadzony przez PARP w latach 2009, 2010, 2012, bez dalszej kontynuacji, Benchmarking parków technologicznych. Ostatnia jego edycja z roku 2012 zawierała pytania skierowane do lokatorów oceniające operatora / zarządcę parku oraz wpływ parku na sukces firmy („,w jakim stopniu lokalizacja Państwa firmy w parku przyczynia się do sukcesu Państwa firmy?”). Wyniki badania przeprowadzonego w roku 2012 w tym zakresie były in minus - poniżej średniej, co uznawane jest bardziej za ocenę negatywną aniżeli pozytywną wpływu wsparcia parku na sukces lokatorów. Należy jednak zwrócić uwagę na duże odchylenie od średniej (blisko 2,5 pkt). Nieliczni badacze, jak na przykład Kwieciński [2018], podejmują się zadania oceny potencjału firm parkowych. Kwieciński badał m.in. innowacyjność firm-rezydentów, wykorzystując mierniki wielkości nakładów na sferę $\mathrm{B}+\mathrm{R}$ oraz odsetek firm wprowadzających nowe i ulepszone procesy. Według tych badań populacja przedsiębiorstw innowacyjnych w parkach technologicznych w Polsce jest niewielka. Według badań zaledwie $20 \%$ podmiotów gospodarczych można uznać za innowacyjne, $31 \%$ ma ograniczony potencjał do kreowania innowacji, natomiast aż połowa lokatorów uznana została za przedsiębiorstwa nieinnowacyjne.

\section{Podsumowanie}

Podsumowując wyniki przeprowadzonego przeglądu literatury, można sformułować następujące wnioski. Badania porównawcze osiąganych wyników ekonomicznych przez firmy lokatorów parków technologicznych z grupa firm zlokalizowanych poza parkiem są jedna z metod oceny efektywności parków technologicznych, obok badania wpływu tych inwestycji na rozwój regionów, w których funkcjonują oraz ich powiązań z instytucjami naukowymi.

Trudność badania efektywności parku na bazie porównania firm z i spoza parku polega na samym sposobie i kryteriach doboru próbki firm spoza parku do badania porównawczego. W literaturze brak jednolitego podejścia w tym zakresie, być może dlatego badania tego typu nie są tak popularne jak samych parków bądź firm parkowych w wybranych krajach, również w Polsce.

Badania wskazane $\mathrm{w}$ artykule, w szczególności realizowane na świecie, wykorzystują w większości miary dotyczące wyników (innovative outputs), nie odnoszą się natomiast do miar nakładów (innovative inputs). Autorzy skupiają się na wynikach finansowych przedsiębiorstw, liczbie patentów, liczbie projektów badawczo-rozwojowych, liczbie produktów i usług, jak również intensywności kooperacji z sektorem nauki. Dobór mierników jest zazwyczaj dopasowany do rodzaju badania i mocno subiektywny, dlatego badania innowacyjności firm parkowych w tym zakresie są mało porównywalne. Badania realizowane w Polsce częściej natomiast prezentują ogólny obraz firm parkowych, maja charakter sprawozdawczy, nie ujmują badania relacji $z$ innymi zmiennymi, w tym wpływu na wyniki firm. Nie zidentyfikowano również badań porównawczych pomiędzy firmami parkowymi oraz tymi zlokalizowanymi 
w parkach technologicznych i są mniej popularne niż badania samych ośrodków innowacji.

$\mathrm{Na}$ podstawie przeglądu wyników badań można stwierdzić, że nie ma zgodności wśród badaczy co do tego, czy firmy ulokowane w parkach technologicznych sa bardziej innowacyjne niż te spoza tego typu instytucji. Część badaczy podkreśla, że firmy parkowe uzyskuja lepsze wyniki zarówno finansowe, jak i pozafinansowe lub są aktywniejsze w implementacji projektów innowacyjnych i intensywności współpracy z sektorem nauki [Squicciarini, 2008; Siegel et.al., 2003; Lindelöf, Löfsten, 2002; Albahari at al., 2013]. Istnieją również prace badawcze, w których autorzy nie odnotowali istotnej statystycznie różnicy pomiędzy innowacyjnością firm ulokowanych w parkach technologicznych i tymi, które funkcjonuja poza infrastruktura [Westhead, 2002; Lindelöf, Löfsten, 2003; Chan et. al., 2010].

Warto pogłębiać badania w celu wyjaśnienia przyczyn otrzymywanych przez badaczy wyników, wnioski bowiem moga mieć realny wpływ na zastosowanie w praktyce przez menedżerów parków technologicznych. Zasadne wydaje się również zweryfikowanie tego, według jakich kryteriów rekrutowane są firmy do parków technologicznych, jak weryfikowany jest poziom ich innowacyjności i gotowości, jak rozumiana jest innowacyjność w tego typów instytucjach oraz kto ocenia ich potencjał oraz dopasowuje ścieżkę rozwoju firmy w ośrodku.

\section{Literatura}

Albahari A., 2019, Heterogeneity as a Key for Understanding Science and Technology Park Effects, [in:] Science and Technology Parks and Regional Economic Development, Amoroso S., Link A., Wright M. (eds.), Palgrave Advances in the Economics of Innovation and Technology, Palgrave Macmillan, Cham.

Albahari A., Barge-Gil A., Pérez-Canto S., Modrego-Rico A., 2013, The Influence of Science and Technology Park Characteristics on Firms' Innovation Results, MPRA Paper, No. 48829, pp. 1-27.

Allen J., 2007, Third Generation Science Parks, Manchester Science Parks, Manchester, UK.

Borowy M., Mażewska M., Rudawska J., 2020, Innowacyjnośc $i$ internacjonalizacja przedsiebiorstw driałajacych w polskich parkach i inkubatorach technologicznych w kontekście wyzwań Przemystu 4.0, SOOIPP Wydawnictwo SGGW, Warszawa.

Cardy R., Leonard B., 2014, Performance Management: Concepts, Skills and Exercises: Concepts, Skills and Exercises, Routledge, New York, pp. 280, DOI: 10.4324/9781315 701790.

Chan K-Y., Oerlemans L., Pretorius M.W., 2010, Knowledge exchange behaviours of science park firm: The innovation bub case, „Technology Analysis and Strategic Management", vol. 22(2), pp. 207-228, DOI: 10.1080/09537320903498546.

Colombo G., Delmastro M., 2002, How effective are technology incubators? Evidence from Italy (Research Policy), „Research Policy”, vol. 31(7), pp. 1103-1122.

Dabrowska J., 2011, Measuring the success of science parks: performance monitoring and evaluation, World Conference on Science and Technology Parks, Copenhagen, Denmark. 
Evaluation of the past and future economic contribution of the UK Science Park Movement, 2003, ANGLE Technology, UKSPA.

Ferguson R., Olofsson Ch., 2004, Science Parks and the Development of NTBFs: Location, Survival and Growth, „The Journal of Technology Transfer”, vol. 29, pp. 5-17.

Fukagawa N., 2006, Science Parks in Japan and their value-added contributions to new technology-based firms, „International Journal of Industrial Organization”, vol. 24(2), pp. 381-400.

Gotowosí Ośrodkón Innowacii do wspierania inteligentnej specjalizacji gospodarki, 2021, Pokorski J. (red.), PARP, Ministerstwo Rozwoju, Pracy i Technologii, Warszawa.

Hołub-Iwan J., Olczak A.B., Cheba K., 2012, Benchmarking parków technologicznych w Polsce, PARP, Warszawa.

IASP Statistics, 2018, http://www.iasp.ws/Our-industry/Statistics [data dostępu: 11.12.2020].

Innowacje i transfer technologii. Stownik pojeć, 2005, Matusiak K.B. (red.), PARP, Warszawa.

Kwieciński L., 2018, Polskie parki technologiczne - w strone IV generacji parków technologicznych. Wstępne wyniki badań terenowych, „Zarządzanie Publiczne”, nr 1(43), s. 38-53, DOI: 10.15678/ZP.2018.43.1.03.

Lamperti F., Mavilia R., Castellini S., 2017, The Role of Science Parks: A Puгzle of Growth, Innovation and R\&D Investments, „The Journal of Technology Transfer”, vol. 52, pp. 158-183, DOI: 10.1007/s10961-015-9455-2.

Lindelöf H., Löfsten P., 2002, Science Parks and the growth of new technology-based firms academic-industry links, innovation and markets, „Reseach Policy”, vol. 31, pp. 859-876.

Lindelöf H., Löfsten P., 2003, Science Park Location and New Technology-Based Firms in Sweden: Implications for Strategy and Performance, „Small Business Economics”, vol. 20, pp. 245-258, DOI: 10.1023/A:1022861823493.

Lindelöf H., Löfsten P., 2004, Proximity as a Resource Base for Competitive Advantage: University - Industry Links for Technology Transfer, „The Journal of Technology Transfer", vol. 29(3-4), pp. 311-326, DOI: 10.1023/B:JOTT.0000034125.29979.

Lindelöf H., Löfsten P., 2005, R and D networks and product innovation patters - academic and non-academic new technology-based firms on science parks, „Technovation”, vol. 25(9), pp. 1025-1037, DOI: 10.1016/j.technovation.2004.02.007.

Lyra R.M., Almeida M.F.L., 2018, Measuring the performance of Science and Technology Parks: a proposal of a multidimensional model, "Journal of Physics: Conference Series", No. 1044, DOI: $10.1088 / 1742-6596 / 1044 / 1 / 012042$.

Malairaja C., Zawdie G., 2008, Science Parks and University-Industry Collaboration in Malaysia, Technology Analysis\& Strategic Management, vol. 20(6), pp. 727-739, DOI: 10.1080/09537320802426432.

Mażewska M., Tórz A., 2019, Raport z badania parków technologicznych 2019, SOOIPP, Poznań-Warszawa.

Monck C., Peters K., 2009, Science Parks as an Instrument of Regional Competitiveness: Measuring Success and Impact, IASP 2009 Conference proceedings, pp. 1-19. https: //www.sqw.co.uk/files/8113/8712/8061/57.pdf [data dostępu: 16.05.2021].

Pelle D., Bober M., Lis M., 2008, Parki technologiczne jako instrument polityki wspierania innowacji dyfusji wiedş, Instytut Badań Strukturalnych, Warszawa. 
Prezentacja nyników badan o firmach driałajacych w parkach $i$ inkubatorach technologicznych w Polsce w 2017 r., 2017, SOOIPP, Poznań - Warszawa.

Raport o firmach dziatajacych w parkach $i$ inkubatorach technologicznych w Polsce w 2012 r., 2012, SOOIPP, Poznań - Warszawa.

Raport o firmach driatajacych w parkach i inkubatorach technologicznych w Polsce w 2013 r., 2014, SOOIPP, Poznań - Warszawa.

Rowe D., 2003, Evolution Applies to Science Parks Too, [in:] Frontiers of Entrepreneurship and Innovation. Readings in Science Park Policies and Practice, Formica P.I., Sanz L. (eds.), IASP, Malaga.

Siegel D., Westhead P., Wright M., 2003, Assessing the impact of university science parks on research productivity: explanatory firm-level evidence from United Kingdom, „International Journal of Industrial Organization", vol. 21(9), pp. 1357-1369.

Squicciarini M., 2008, Science Parks' tenants versus out-of-Park firms: who innovates more? A duration model, ,The Journal of Technology Transfer”, vol. 33, pp. 45-71, DOI: 10.1007/s10961-007-9037-z.

Strategiczne obszary rozwoju parkón technologicznych, 2011, Matusiak K.B. (red.), PARP, Warszawa.

Vásquez-Urriago A.R, Barge-Gil A., Modrego Rico A., 2016, Science and Technology Parks and Cooperation for Innovation: Empirical Evidence from Spain, „Research Policy”, vol. 45(1), pp. 137-147. DOI: 10.1016/j.respol.2015.07.006.

Vásquez-Urriago A.R., Barge-Gil A., Paraskevopoulou E., 2011, The impact of science and technology parks on firms' product innovation: empirical evidence from Spain, „MPRA”, Paper 30555.

Westhead P., 2002, R and D Inputs' and 'Outputs' of Technology-Based Firms Located on and off Science Parks, „R\& D Management”, vol. 27(1), pp. 45-62, DOI: 10.1111/ 1467-9310.00041.

Wójcik-Karpacz A., Rudawska J., 2016, Instytucjonalne formy wspierania przedsiębiorczości, „Prace Naukowe Uniwersytetu Ekonomicznego we Wrocławiu”, nr 419, s. 248264, DOI: 10.15611/pn.2016.419.22.

Yang Ch-H, Motohashi K., Chen J-R., 2009, Are new technology-based firms located on science parks really more innovative? Evidence from Taiwan, „Research Policy”, vol. 38(1), pp. 77-85.

www 1, http://www.sooipp.org.pl [data dostępu: 11.12.2020]. 